\title{
The Twelfth-Century Story of Daniel for Performance by Hilarius: An Introduction, Translation, and Commentary
}

This article introduces Hilarius's underappreciated work Historia de Daniel Representanda [The Story of Daniel for Performance] to a wider readership by translating it into English for the first time. It summarizes what is known about the play's author, sources, and manner of performance. Hilarius's play is thematically complex, depicting the opposition between secular and spiritual kingship in ways that echo how medieval exegetes interpreted Daniel's adventures at Belshazzar's feast and in the lions' den (Dan. 5-6) as prefigurations of the sacrament of the Eucharist. This work therefore represents a significant artistic achievement worthy of attention in its own right, not merely as the poor cousin of the Beauvais Ludus Danielis.

\section{Introduction}

Historia de Daniel Representanda [The Story of Daniel for Performance] is one of three highly accomplished music-dramas that Hilarius (fl. 1125), an Augustinian canon and self-described follower of Peter Abelard, composed. ${ }^{1}$ The introduction to the text that follows has three purposes: first and foremost, to introduce an important but largely neglected twelfth-century liturgical drama to a wider circle of readers by translating it into English for the first time; second, to elucidate Hilarius's work by providing a detailed commentary on the text itself and by considering what is known about its author, sources, and manner of performance; and finally, to enhance our understanding of the play's thematic complexity by considering how Hilarius depicts the opposition between secular and spiritual kingship, and how medieval exegetes interpreted Daniel's adventures at Belshazzar's feast and in the lions' den (Dan. 5-6) as prefigurations of the sacrament of the Eucharist.

Stephen K. Wright (wrights@cua.edu), ordinary professor of English at the Catholic University of America (Washington, DC), is the author of The Erlau Playbook: Five Medieval German Plays for Christmas and Easter (forthcoming). 
Although Hilarius's treatment of the story of Daniel at the Babylonian court is rich in poetic and dramatic artistry, the more famous thirteenthcentury Ludus Danielis from Beauvais cathedral has long overshadowed it. The latter, a musical and poetic tour de force that draws upon the same subject matter, is surely the best known and most often performed work in the entire corpus of the Latin music-drama. ${ }^{2}$ By way of contrast, critics scarcely mention Hilarius's work except in discussions of its provenance and possible affiliation with its counterpart from Beauvais. ${ }^{3}$ The lack of extant musical notation for Hilarius's Story of Daniel has clearly contributed to this history of scholarly neglect. The play nevertheless represents a considerable artistic achievement and deserves attention in its own right, not merely as the poor cousin of the undeniable masterpiece created by and for the young people (juventus) of Beauvais. ${ }^{4}$

\section{What We Know about Hilarius}

Hilarius is one of the very few named authors in a genre whose creators mostly remained anonymous. ${ }^{5}$ Because one of his poems recounts the life of an English recluse (Eve of Winchester), and four of his letters are written to English recipients (one to a nun named Rose, one to William of Anfonia, and two to an unnamed English boy), early commentators thought that Hilarius was himself English by birth and often referred to the poet as Hilarius Anglicus or Hilary the Englishman. More recently, however, research has shown that Eve of Winchester lived at a monastery in Angers, the city where Hilarius spent part of his life as well. The nun Rose lived at the nearby convent of Ronceray, the schoolboy was most likely one of Hilarius's pupils, and 'Anfonia' is clearly not an English place name. Because all of Hilarius's remaining letters are addressed to recipients in Angers, Orléans, and Nantes, and because two of his plays and several of his poems contain phrases in idiomatic Old French, it seems safe to conclude that he was a native of either Angers or Orléans. ${ }^{6}$ Certainly he studied under Peter Abelard (1079-1142), to whom he addressed a poem around 1125 , when the great scholastic withdrew to the oratory of the Paraclete. The poem, composed in ten rhymed Latin quatrains with a French refrain, refers to an incident in which an indiscreet servant divulged to Abelard that Hilarius and his companions had been misbehaving, causing the master to suspend his lectures and banish the students to the village of Quinçai. The comic lament curses the informer as a despicable peasant ('detestandus est ille rusticus') and depicts the poet questioning himself about his reluctance to depart with the others: 
Quid, Hilari, quid ergo dubitas? Cur non abis et uillam habitas? Sed te tenet diei breuitas, Iter longum et tua grauitas.

Tort a uers nos li mestre.
Why, Hilarius, why do you hesitate?

Why don't you go away and live on the farm? But you are held back by the shortness of the day, the length of the road, and your own corpulence.

The master has done us wrong! ${ }^{7}$

A collection of twelve short letters purportedly by, to, or about Hilarius allows the construction of a minimal, highly speculative account of his movements and associations. ${ }^{8}$ There is no way to ascertain whether he was the same individual whom William of Tyre and Arnulf of Orléans mention as being a distinguished teacher at Orléans sometime around 1145-1150, or whether he and the 'Hilarius clericus et canonicus' noted in an undated entry in a necrology from the Augustinian abbey of St Victor in Paris were the same person. In short, the details of Hilarius's life first as a wandering scholar and later as an established canon at Ronceray are elusive at best, but David Bevington is surely right to conclude that he was 'a conscious literary artist, the first such poet of the theater whom we can identify.'?

A single manuscript consisting of a mere sixteen leaves contains all but one of the poetic works attributed to Hilarius. Preserved for many years at the library of Rosny, this slender codex is now housed in Paris in the Bibliothèque Nationale. ${ }^{10}$ The contents, including fifteen pieces by Hilarius all of which are composed in rhymed Latin verse, appear in a clear miniscule dating from the twelfth century. ${ }^{11}$ The entries include the previously mentioned vita of Eve of Winchester and four verse letters to three other women religious (Bona, Superba, and Rose), a poem in praise the author's residence at Caliastrum (the priory of Chalautre-la-Petite near Sens), a scathing anti-papal satire, and the verse epistles to Peter Abelard and the otherwise unknown William of Anfonia. The explicitly erotic letter to a boy from Angers and two others to an English boy express physical attraction as well as personal affection. ${ }^{12}$ Most important for our purposes, the manuscript also preserves the complete texts of three dramas on sacred subjects: The Raising of Lazarus (ff $9 \mathrm{r}-10 \mathrm{v}$ ), The Play of the Image of St. Nicholas (ff 11r-12r), and The Story of Daniel for Performance (ff $12 \mathrm{v}-16 \mathrm{r}$ ). ${ }^{13}$ Karl Young judiciously sums up the heterogeneous nature of the book as follows: 'In the agreeable mélange are expressed sly merriment, outspoken anger, equivocal amorousness, pious laudation, and dramatic tension'. ${ }^{14}$ Finally, the cartulary of the convent at Ronceray preserves a rhymed Latin account of a dispute in which the nuns 
were involved, the 'Iudicium de calumnia molendini Briesarte', ascribed to a certain 'Hilarius Canonicus' whose name appears elsewhere in the cartulary. Paul Marchegay plausibly attributes the poem to our Hilarius and dates it to about $1122 .{ }^{15}$

\section{The Manuscript of the Play}

Hilarius's Story of Daniel is a compact bipartite work running to 336 lines of rhymed Latin verse. ${ }^{16}$ The first section of the play (1-175.1-4) depicts Belshazzar's feast: the defiling of the sacred vessels plundered by Nebuchadnezzar from the Temple in Jerusalem, the mysterious appearance of a disembodied hand that inscribes three enigmatic words on the wall of the royal banquet hall, Daniel's interpretation of the prophecy, and the sudden downfall of Belshazzar at the hands of Darius's invading army. The second episode presents the familiar story of Daniel in the lions' den, wherein Daniel is condemned for his refusal to worship Darius the Mede but an angel sent by God saves the prophet from death (176-336). Although no musical notation accompanies the text, the use of the gerundive in the incipit (representanda) and the inclusion of stage directions and speech prefixes establish that Hilarius intended Story of Daniel for performance at either matins or vespers sometime during the Christmas season. ${ }^{17}$

The Beauvais play is preserved as an integral part of the ceremonies for the feast of the Circumcision (1 January) from Beauvais cathedral, making clear the occasion for which the performance was intended. ${ }^{18}$ Margot Fassler argues persuasively that the young subdeacons of the cathedral school composed a play featuring a youthful protagonist as part of a deliberate effort to reform the carnivalesque excesses and inversions associated with the season's feast of fools:

It permits folly and discord, but within an orthodox context, and its goals are to suppress certain aspects of well-established popular traditions by bringing them into the church and containing them within larger liturgical and exegetical traditions. ${ }^{19}$

Because an anthology of his poetic works rather than a service book preserves Hilarius's play, the precise liturgical setting for its performance is unclear. One could certainly argue by analogy with the Beauvais Ludus Danielis that the Historia de Daniel Representanda was intended for performance on 1 January. By the same token, however, possibly it was meant to be staged 
a week later on the feast of the Epiphany (6 January). The play's closing hymn, Nuntium vobis fero, explicitly celebrates the adoration of the Magi and explicates the trinitarian symbolism of their three gifts. ${ }^{20}$ Twelfth- and thirteenth-century versions of the Officium Stellae, the paraliturgical representation of the journey of the Magi composed for the office of Epiphany, also include this hymn. ${ }^{21}$ Twelfth-century typological pairings in the visual arts sometimes equate Habakkuk's gift of food to Daniel with the presentation of the gifts of the Magi to the Christ-child. ${ }^{22}$ In short, Hilarius clearly meant his play to be staged at Christmastide, but whether for the feast of the Circumcision or Epiphany is impossible to ascertain.

As is the case with the other two plays in the manuscript, The Story of Daniel opens by enumerating the necessary dramatis personae. The first part required eleven actors, the second fourteen, not counting any silent supernumeraries such as soldiers for the battle scene and lions to devour Daniel's accusers. A performance would require only a few loca for the principal episodes. Belshazzar's feast takes place entirely within his spacious palace and thus requires only a single station. The second part of the play would require no more than four stations, namely, the same throne room as in part one, the house in which Daniel secretly says his prayers, the lions' den, and the field from which Habakkuk is plucked while attempting to feed his reapers. The battle between the small armies of Belshazzar and Darius could take place either within the fixed acting station representing the palace or in the undifferentiated playing space of the platea. In terms of its cast size and number of requisite loca, then, The Story of Daniel could easily be staged within the sanctuary of even a modest church building.

The Story of Daniel suggests performance just before the end of either matins or vespers (336.1-5), but the play is notably free of direct borrowings from the divine office. There are no hymns, antiphons, responsories, or other liturgical materials except for the final rubrics directing an angel to sing the nativity hymn Nuntium vobis fero and for the actor in the role of Darius to begin singing the play's sole piece of plainchant from the divine office, either the Te Deum or the Magnificat. ${ }^{23}$ The text instead consists of newly composed rhymed strophes remarkable for their polished tone, supple syntax, sophisticated (but never recondite) diction, and metrical variety. Karl Young, who devotes more carefully nuanced attention to matters of style than any other reader of the play, emphasizes its 'richness of literary quality' and elucidates the gravity and solemnity of both individual and choral speeches: 
The processional pieces, or conductus, which mark the entrance of important personages, produce an effect of stateliness, and provide effective comment upon the turns in the action. In their unbridled eloquence these pieces may, at times, approach a certain tumidity, as in the lines to the queen (1l. 87 sqq.) ... Such pomposity, however, is scarcely more than the situation demands, and must, in general, be commended for its fluency. The desire for a somewhat inflated style and for a highly ceremonious tone may account for the absence of the vernacular refrains which are found in the other two plays of this author. ${ }^{24}$

As Young emphasizes, the unmistakable formality of diction is altogether appropriate for the setting at a royal court and for the seriousness of the subject matter. Similarly, Grace Frank enthusiastically celebrates the diversity, artfulness, and appropriateness of the dialogue:

The variety of action and character in the play is reflected in its vocabulary and versification. Tone, rhythm, and rhyme change with the speakers and their moods. The text proceeds from long and stately verses with rich rhymes to short, staccato stanzas, from lines with many liturgical overtones to lines reminiscent of the goliards. Indeed the whole play reminds one of those medieval tapestries in which the combined wealth of colour, pattern, and movement creates a jewellike impression. ${ }^{25}$

The astonishing variety of metrical forms that Hilarius employs further enlivens the many subtly calibrated linguistic registers. Although the work runs to a mere 336 lines of verse, it contains more than thirty distinct stanzaic forms, only a scant handful of which repeat elsewhere in the text. ${ }^{26}$ Rather than relying on classical forms, the verse is accentual and highly rhythmic, recalling the goliardic lyrics of Hilarius and his fellow vagantes. Although no musical notation for the play survives, the strophic forms so clearly resemble those of the Beauvais Ludus Danielis that William Smoldon's description of the latter — its 'dance-like measures' and 'highly organized melodies of the troubadour type' - likely apply to the lost music of Hilarius's work as well. Recalling that its companion piece from Beauvais contains 'a vast storehouse of secular music', readers feel even more keenly the loss of the original notation for Hilarius's work. ${ }^{27}$ Even though he was writing within the constraints of a sacred observance, Hilarius clearly revelled in his role as an artist with an inexhaustible talent for poetic (and perhaps musical) innovation. 
One other enigmatic aspect of the manuscript deserves mention in any discussion of The Story of Daniel. Four male proper names are recorded at twelve different places in the manuscript: Hilarius five times $(76,176,213$, 267.1-2, 286), Iordanus four times (0.1-2, 156, 203.1, 330.1), Simon twice (238.1-3, 275), and Hugo once (52). The names always occur at the end of a rubric or at the first line of a new speech, and they are all crossed through with a red line. Readers have sometimes been tempted to think of these four individuals as collaborators in either the performance or the composition of the play, although there are serious problems with both hypotheses. One can more safely conclude that these are not the names of actors assigned to various parts, since seven of the twelve parts that follow the names are for groups rather than individuals. While a certain amount of role-doubling might be expected, Hilarius could not easily play Darius's soldiers (175.1-4, 203.1), Darius himself (267.1-1), and Daniel (286.1), while at the same time his companion Iordanus impersonated Darius's soldiers (203.1) and Daniel (330.1). By the same token, the fact that five of the names occur next to individual speeches rather than group roles seems to rule out Du Méril's hypothesis that they refer to the individuals assigned to lead the chorus at various points in the play. ${ }^{28}$ John Bernard Fuller speculates that Hilarius composed the play in its entirety and, at some later date, a witness to one or more performances tried to add the names of the players from memory but got confused, resulting in the inconsistent role assignments. ${ }^{29}$ The existence of a scribe with a faulty memory is, of course, possible if ultimately unprovable, but the notion of recording the names of individual star players would seem to be more consistent with the professional companies of later centuries than with the worship practices of twelfth-century clerics. Finally, one could understand the names to be those of four poets who all contributed various passages to the play. ${ }^{30}$ As Young notes, this collaboration might help explain the surprising variety of stanzaic patterns noted above, but ascertaining the amount written by each person would still be difficult. Perhaps each contributor composed the passage extending from his name up to the next appearance of the name of a colleague. ${ }^{31}$ Since a later scribal hand clearly added the entries, however, they do not bear overmuch weight as evidence for either collaborative composition or performance history of the play. ${ }^{32}$

Hilarius's drama appealed to its audience of twelfth-century worshippers not only through its verbal and musical artistry but also through a variety of visual means. Those responsible for staging this paraliturgical performance presumably would have employed whatever means were available to 
suggest the splendour of the courts of Belshazzar and Darius. The stage directions and dialogue establish that the royal palace must have featured at least two thrones $(0.1-2,148,175.1-4,238.1,312.2-3)$ and probably a banquet table. A sceptre (3) and the crown that is later seized by Darius the Mede (175.1-4) indicate Belshazzar's status. Although Daniel's humility makes him disinclined to accept material rewards for his work as prophet and advisor to the two kings (136-7, 235-8), he nevertheless wears sumptuous purple robes $(74,145.1-2,146-7)$ and receives a torques - a necklace made of twisted strands of gold (73). The costume and ornaments of Belshazzar and his queen must have been no less splendid, for in bestowing this rich attire upon the prophet, the king makes him 'like unto himself' (145.1-2). No explicit evidence for the costumes worn by the soldiers, elders, Habakkuk, or the three angels exists, but some attempt was probably made to mark their status. The descriptions of costumes from an early thirteenth-century Ordo prophetarum at Laon Cathedral might shed light on how two of the characters appeared: 'Daniel, a young man clothed in a splendid garment' and 'Habakkuk, bearded, bent over, hunch-backed'.33 Finally, Karl Young plausibly speculates that the lions 'may have been represented by persons dressed in skins and masks. ${ }^{34}$

Appropriate stage properties appear throughout the play. In addition to whatever distinctive costumes they may have worn, the soldiers in Belshazzar's retinue may have played harps or other stringed instruments (citaris, 12) as they escorted the monarch in a majestic entry procession (pompa, 0.1-2). ${ }^{35}$ During the battle between the armies of Belshazzar and Darius, one imagines that the soldiers brandished weapons of some kind, similar to the sword that Daniel's guardian angel wields when he shuts the mouths of the lions (275.1-3). The farm labourers' simple dinner (prandium, 275.1-3, 276-9, 287-92) that Habakkuk unwillingly donates to Daniel provides a positive counterbalance to the lavish meal (opus prandii, 15) that profanes the sacred vessels at Belshazzar's feast. The most spectacular stage properties of all were undoubtedly the 'vessels of the sanctuary' (15) that Belshazzar orders be brought forth for use at his unruly banquet (18.1), only to have them removed from his presence after Daniel interprets the dire warning that the ghostly hand writes upon his wall (155.1-2). These splendid objects were 'vessels of the sanctuary' in two senses of the phrase, inasmuch as they represent the sacred treasures of silver and gold looted from the Temple during Nebuchadnezzar's conquest of Jerusalem (Dan. 5:2-3) and were almost 

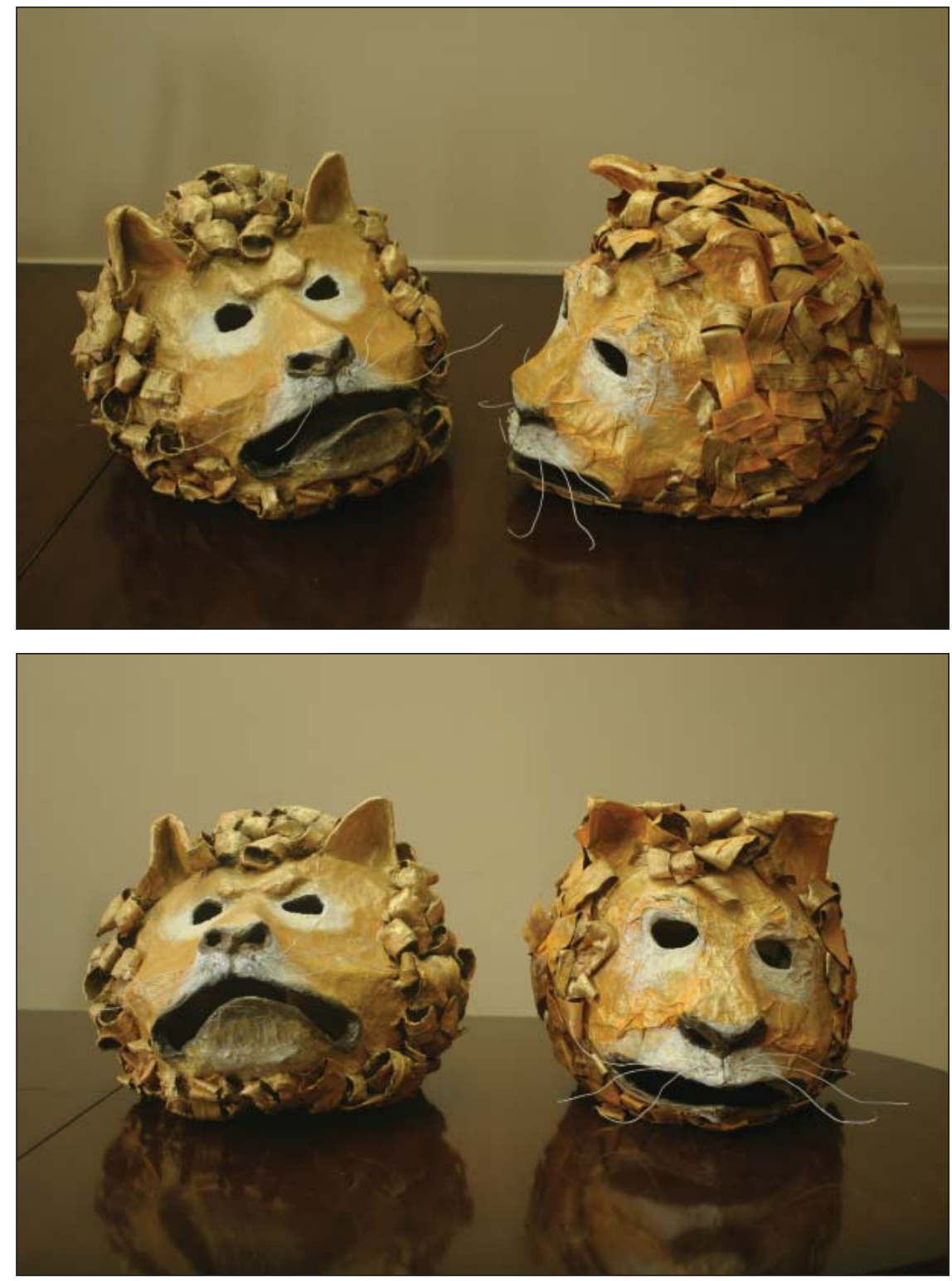

Lion head masks, from the Toronto Consort and PLS production of The Play of Daniel (1981). Photographer: Katherine Belyea, 2014. 
certainly obtained from the sacristy of the very church in which the performance was being staged.

David Bevington has observed that in his Raising of Lazarus Hilarius shows far more interest in the creation of 'richly poetic language' than in the depiction of movement, action, or conflict. ${ }^{36}$ The Story of Daniel, however, does not suggest the 'tentative nature of his theatrical arrangements'. Without sacrificing any of his usual poetic vitality, Hilarius invites the spectator's eye to feast on movement, spectacle, and what might even be called special effects. To begin with, Hilarius calls for no fewer than five processions, each of which is accompanied by a musical conductus: the entry of Belshazzar and his retinue $(0.1-2,1-13)$, the entry of the queen and her military escort (76.1-2, 77-97), the entry of Daniel and the soldiers (107.1, 108-28), the exit of the queen during the removal of the vessels from the banquet hall (155.1-2, 156-75), and the conductus for Darius at his self-coronation (175.1-4, 176-97). In addition to these formal group movements, the text explicitly requires numerous actions and gestures. Karl Young conjectures that during the song accompanying the arrival of the precious objects from the Temple, 'the revelling of the king and the defiling of the sacred vessels proceed riotously'. ${ }^{37}$ In a brilliant coup de théâtre, a disembodied right hand appears above Belshazzar's head to inscribe its cryptic warning on the wall: 'Mane, Techel, Phares' (47.1-4; 52-66). The text does not divulge the precise technique employed to achieve this effect, but surely the performers strove to execute it so as to maximize eerie sensations. Stage directions instruct the elders to move off to one side while they confer in whispers (66.1-2) and the soldiers to leave the throne room to fetch Daniel (106-7) and bring him back (107.1). In order to bring the first part of the play to a close, a detailed stage direction instructs Darius (and his army) to engage in pantomime combat with Belshazzar, kill him, seize his crown, and take a seat upon his now vacant throne (175.1-4). Daniel departs from the main playing area alone in order to pray in secret (251.1-2). After Daniel's sacrilege has been discovered, Darius's soldiers lead him off to the lions' den with the irate king following him to the edge of the pit (267.1-2, 271.1). A heretofore concealed angel armed with a sword suddenly appears in order to 'shut the mouths of the lions', accompanied by silent gestures at which we can only guess (275.1-2). ${ }^{38}$ In order to sustain the imprisoned protagonist, a second angel comes to Habakkuk, a farmer who is carrying a meal to the mowers in his fields (275.1-3). When Habakkuk professes his ignorance of Daniel's whereabouts, the angel unceremoniously lifts him by the hair and takes him 
to the lions' den (281.1-2). At the play's climax, Daniel's envious accusers are 'put into the pit so that they might be devoured by the lions' (312.1-4), most likely performed as yet another violent pantomime. Darius takes Daniel by the hand and personally leads him back to his throne (312.1-3). Daniel's joyful prophecy of the future coming of the true king of kings and the cessation of earthly kingdoms (331-6) then provides a positive counterbalance to the dire prophecy inscribed on Belshazzar's wall. A third angel suddenly appears, perhaps 'from on high' as the first line of his hymn proclaims, in order to confirm the truth of Daniel's prophecy by announcing that 'Christ is born, the ruler of the world', the new king who must be worshiped by the princes of the east (336.1-5; see also the Appendix). ${ }^{39}$ Hilarius's Story of Daniel thus offers a striking example of twelfth-century stagecraft, synthesizing poetry, music, costumes, stage properties, movement, and special effects in order to enhance the devotional experience of worshipers at Christmastide.

\section{Iconography as an Indication of Exegetical Complexity}

Glynne Wickham's comment that the play's representation of two imperfect pagan kings who in the fullness of time will be superseded by the true dominator orbis, the perfect ruler whose advent is both prophesied and prefigured by Daniel, suggests that the unseen protagonist of the play is none other than Christ the king. ${ }^{40}$ While the contrast between earthly and divine kingship is indeed a crucial and recurring theme throughout the play, medieval interpreters thought the characters and episodes that form the subject of Hilarius's work possessed an even wider range of symbolic significance. Christian exegetes not only accepted Daniel as one of the four major prophets (Matt. 24:15 and Mark 13:14), but in medieval typological thinking, Daniel himself also foreshadowed Christ both through his prophecy of the coming of the messiah and through his rescue from the lions' den, which prefigured Christ's bodily resurrection from the tomb, the release of the souls of the just at the Harrowing of Hell, and the deliverance of faithful Christians at the Last Judgment. Other interpreters saw Daniel as the wise judge, the interpreter of dreams, a symbol of celibacy in the church, a representative of the three theological virtues (faith, hope, and charity), an illustration of the power of prayer, an example of how God rewards those who fast or do penance, or a type of the contemplative monk. Because Habakkuk could pass into the lions' den without breaking the seal placed there by the king and his nobles (a conflation of Dan. 6:17 and 14:35), some even read the episode as a foreshadowing of the virgin birth of Christ. Habakkuk also figures as one of the liberated patriarchs 
in many depictions of the Harrowing of Hell and, as will be discussed in greater detail below, as a foreshadowing of the Christian priest offering the sacrifice of the mass. ${ }^{41}$

The playwright's foregrounding of certain tangible objects undoubtedly situates the performance in the world of everyday reality, but at the same time it sheds a kind of oblique light on otherwise unsuspected thematic concerns. As a case in point, a mundane set of closely related objects and actions provides a different perspective on the thematic unity of this curious bipartite work. Both Hilarius's play and its biblical source repeatedly describe the simple of act of consuming food and drink, providing another context for understanding the theological significance of the work. The Book of Daniel both begins and ends with characters who are eating or being eaten. The opening episode (Dan. 1:1-16) depicts a version of the so-called 'food test'. Nebuchadnezzar orders that for the next three years, the young Hebrew captives from Jerusalem should dine on the same food and wine as that which graces his own table, but Daniel refuses so that 'he might not be defiled'. After a mere ten days, a simple diet of vegetables and water leaves Daniel and his companions noticeably 'fairer and fatter than the children that ate of the king's meat' (Dan. 1:15). ${ }^{42}$ Nebuchadnezzar fares less well in terms of his own nourishment. As a punishment for his pride, the king is afflicted with insanity for seven years, during which time he 'was driven away from among men, and did eat grass, like an ox' (Dan. 4:29-30, 5:21). Immediately following and closely connected to the episode of Nebuchadnezzar living among the ruminants are the well-known stories of Belshazzar's feast (Dan. 5:1-30) and Daniel in the lions' den (Dan. 6:1-28), both of which reiterate the leitmotif of perverse eating. ${ }^{43}$ Belshazzar, already drunk at his own banquet, defiles the sacred gold and silver vessels that his father had plundered from the Temple in Jerusalem by using them to serve yet more wine to a thousand of his nobles, wives, and concubines. Daniel correctly deciphers the three cryptic words that miraculously appear on the wall, and that same night Darius the Mede overthrows Belshazzar. As he had done twice before, Daniel again finds favour with a new ruler, but the king's envious counsellors contrive to have the prophet convicted of sacrilege and lese-majesty, the punishment for which is to be devoured by lions. After sealing Daniel inside the den, Darius becomes so conscience-stricken that he can neither sleep nor eat: 'And the king went away to his house, and laid himself down without taking supper, and meat was not set before him, and even sleep departed from him' (Dan. 6:18). ${ }^{44}$ The episode concludes with a moment of brutal poetic justice, 
for when Daniel is discovered to have been protected throughout his ordeal by a guardian angel, Darius orders his accusers together with their wives and children to be fed to the lions instead, 'and they did not reach the bottom of the den, before the lions caught them, and broke all their bones in pieces' (Dan. 6:24).

The Book of Daniel similarly concludes with a two-part deuterocanonical segment that repeatedly stresses the conjunction between food and worship as a way to contrast the fatuous illegitimacy of the Babylonian deities with the true sovereignty of the Hebrew God. First, Daniel exposes the fraudulent practices of the priests who worship the idol Bel (Dan. 14:1-21). The proof of the god's greatness is said to lie in his ability to consume prodigious amounts of food: 'and there was spent upon him every day twelve great measures of fine flour, and forty sheep, and six vessels of wine' (Dan. 14:2). In what may be the earliest example of the genre of the locked-room mystery, Daniel reveals the secret passage by which the seventy priests of Bel and their wives and children daily enter the sealed chamber in order to dine on the offerings themselves. Second, Daniel destroys the great dragon that the Babylonians worship by feeding it a toxic meal: 'Then Daniel took pitch, and fat, and hair, and boiled them together: and he made lumps, and put them into the dragon's mouth, and the dragon burst asunder' (Dan. 14:26). Daniel's destruction of Bel and the dragon angers the people, and so they try to feed the prophet to seven lions, whose appetites have been deliberately whetted by being deprived of their usual daily menu of two carcasses and two sheep. Although he is imprisoned with the ravenous beasts for six days, they do not eat him, and an angel rescues Daniel by transporting Habakkuk from his fields in Judea to the lions' den in Babylon. Habakkuk had been carrying a meal of 'boiled pottage ... and broken bread in a bowl' to the reapers in his fields, men who were harvesting a crop to provide yet more sustenance for others in the future (Dan. 14:32). Daniel is therefore nourished by wholesome food and rescued from the famished beasts, while his accusers are fed to the lions, 'and they were devoured in a moment before him' (Dan. 14:41).

The play clearly takes over the Book of Daniel's obsession with food as an agent of defilement and doom, nutrition and blessing. Hilarius alludes briefly to the backstory of Nebuchadnezzar's downfall, and he represents in full Belshazzar's feast, Daniel in the lions' den, and Habakkuk's offering of the food originally intended for the reapers. Not surprisingly, in addition to their many other symbolic interpretations of these scenes, medieval exegetes regarded these intertwined narratives as positive types and perverse antitypes 
of the sacrament of the Eucharist. ${ }^{45}$ As early as the late third century, some interpreted Daniel's rescue by Habakkuk, who is held aloft by an angel while carrying the meal meant for his mowers, as a Eucharistic motif. Daniel's prayers took on a specifically Eucharistic character, while the meal furnished by Habakkuk prefigured both the Last Supper and, by extension, the saving food of the consecrated bread and wine of the mass. In some representations of the scene, Habakkuk brings Daniel a fish symbolizing the body of Christ, so that the man from Judea came to be regarded as 'the type of the priest who administers communion. ${ }^{46}$ In visual form, the association of Habakkuk's meal with the Eucharist could be depicted in at least two different ways. The bowl that the angel-borne Habakkuk offers to the starving prophet sometimes appears in oversized dimensions far out of scale with the other components of the design. In accordance with the predilection of medieval artists to enlarge the single most important element of a complex image, the huge chalice-like bowl itself becomes the primary focus of the viewer's attention. ${ }^{47}$ In other cases, a slight pictorial deviation from the biblical account could also serve to emphasize the prefigurative nature of Habakkuk's gift. According to Daniel 14:32, Habakkuk had already mixed pieces of broken bread into a single bowl of stew that he had cooked for his workers before he set out for the field. In many Romanesque sculptures and miniatures dating from precisely the time of Hilarius's play, however, Habakkuk clearly serves Daniel from not one but two separate vessels, rendered so as to suggest the paten and chalice of the mass. ${ }^{48}$ Such representations underscore that the divinely ordained provision of a saving meal by the priestlike figure of Habakkuk counterbalances the desecration of the vessels at Belshazzar's feast.

The emphasis on Eucharistic imagery in Hilarius's Story of Daniel raises the question of the connection between the choice of subject matter and the play's obvious association with Christmastide. The answer would seem to be threefold. First, medieval commentators understood the prophecies of Daniel (especially Dan. 7:13 and 9:24-7) and of the prophet Habakkuk (Heb. $3: 2$ in the Old Latin version), both of whom appear in the Ordo Prophetarum ceremonies for the Christmas season, to foretell the incarnation of Christ. Second, medieval exegetes regarded Habakkuk's miraculous entry into the sealed lions' den (Dan. 6:17, 14:35) as a prefiguration of the virgin birth of Christ. ${ }^{49}$ Third, artistic works sometimes pair the episode of Daniel and Habakkuk with that of the three Magi presenting their gifts to the Christchild. For example, the four panels of an early twelfth-century capital at StGenou (Berry) combine three scenes from the Old Testament narrative (the 
reapers in the field, the angel transporting Habakkuk, Habakkuk feeding Daniel while a lion devours one of his accusers) with a carving of the Magi arriving in Bethlehem under the guidance of the star. A stylized grapevine, itself a symbol of the Eucharist, encircles all four scenes, drawing them into a single symbolic statement. Elizabeth Saxon explains that 'Habakkuk's feeding of Daniel here prefigures the offering of the Magi, who themselves prefigure the offering of the Church' ${ }^{50}$ In much the same way, Hilarius's drama brilliantly unites Eucharistic antitypes (the desecrations of Nebuchadnezzar and Belshazzar) and types (Daniel and Habakkuk) together with the characters, prophecies, and hymns appropriate to Christmas and its octave. The result is a small miracle of exegetical complexity.

\section{Tentative Conclusion}

Like most introductions, this one cannot be exhaustive. Several worthwhile questions must remain unexplored for the present. For instance, if more were known about the precise social and historical context of Hilarius's composition, would it be possible to read his examination of secular and spiritual kingship as an indirect critique of the political status quo, as Richard Emmerson has so persuasively done for the Beauvais Ludus Danielis? ${ }^{51}$ More detailed comparative studies of Historia de Daniel Representanda and Ludus Danielis are certainly in order, particularly in terms of their use of common iconographical elements and shared strophic forms. Extending a rigorous comparative approach to Hilarius's other two plays would be equally worthwhile. His Raising of Lazarus and Play of the Image of St Nicholas have fascinating counterparts in the famous Fleury playbook, a compilation of ten Latin music-dramas from the late twelfth century copied and preserved in the scriptorium of the Benedictine abbey at St Benoit-sur-Loire, but few have read these major dramatic works in relation to one another. ${ }^{52}$ Although these and other questions far exceed the scope of the present introduction, it is to be hoped that this translation and commentary might provide sufficient stimulus for them to be addressed in the near future.

\section{Notes}

1 The three plays attributed to Hilarius are Suscitacio Lazari [The Raising of Lazarus], Ludus super Iconia Sancti Nicolai [The Play of the Image of St Nicholas], and Historia de Daniel Representanda [The Story of Daniel for Performance]. For editions, 
see. J.J. Champollion-Figeac (ed.), Hilarii versus et ludi (Paris, 1838), 24-39, 4360; Édélestand Du Méril (ed.), Origines latines du théâtre moderne (Paris, 1849; pt Leipzig, 1897), 225-32, 241-54, 272-6; John Bernard Fuller (ed.), Hilarii versus et ludi (New York, 1929), 75-93, 98-117; Karl Young (ed.), Drama of the Medieval Church, 2 vols (Oxford, 1933), 2.211-19, 276-90, 337-43; Nikolaus M. Häring (ed.), 'Die Gedichte und Mysterienspiele des Hilarius von Orléans', Studi medievali, ser 3 (1976), 955-68; and Walther Bulst and M.L. Bulst-Thiele (eds), Hilarii Aurelianensis Versus et Ludi; Epistolae; Ludus Danielis Belouacensis, Mittellateinische Studien und Texte 16 (Leiden, 1989), 36-46, 48-59. David J. Perry (ed.) and Ruth L. Breindel (rev.), The Story of the Prophet Daniel (np, 2009), 56-85, is a seriously defective reprint of Young's text. For an edition and English translation of Hilarius's Play of St Nicholas, see Joseph Quincy Adams (ed.), Chief Pre-Shakespearean Dramas (Boston, 1924), 55-8. For an edition and English translation of Hilarius's Raising of Lazarus, see David Bevington (ed.), Medieval Drama (Boston, 1975), 155-63. For Hilarius's relationship to Abelard, see the discussion below.

2 The definitive edition of the play, its music, and its complete liturgical setting is Wolfgang Arlt (ed.), Ein Festoffizium des Mittelalters aus Beauvais in seiner liturgischen und musikalischen Bedeutung, 2 vols (Cologne, 1970). Other useful editions and translations include Noah Greenberg (ed.), The Play of Daniel: A Thirteenth-Century Musical Drama (New York, 1959); William Lawrence Smoldon (ed.), The Play of Daniel (London, 1960); A. Marcel J. Zijlstra (ed.), 'The Play of Daniel (Ludus Danielis)', in The Play of Daniel: Critical Essays, Dunbar H. Ogden (ed.), Early Drama, Art and Music Monograph Series 24 (Kalamazoo, MI, 1996), 87-126, with a black-andwhite facsimile of the manuscript, plates 1-27; David Wulstan (ed.), The Play of Daniel: A Mediaeval Liturgical Drama (Sutton, Surrey, 1976); Fletcher Collins, Jr. (ed.), Medieval Church Music-Dramas (Charlottesville, VA, 1976), 399-458; Peter Dronke (ed. and trans.), Nine Medieval Latin Plays (Cambridge, 1994), 110-46; Young (ed.), Drama of the Medieval Church, 2.290-306; Bevington (ed. and trans.), Medieval Drama, 137-54; and Bulst and Bulst-Thiele (eds), Hilarii Aurelianensis Versus et Ludi, 99-116. Among the numerous critical, historical, and musicological studies of the play, particularly noteworthy are William L. Smoldon, The Music of the Medieval Church Dramas, Cynthia Bourgeault (ed.), (London, 1980), 224-45; Jerome Taylor, 'Prophetic "Play" and Symbolist "Plot" in the Beauvais Daniel', Comparative Drama 11 (1977), 191-208; Margot Fassler, 'The Feast of Fools and Ludus Danielis: Popular Tradition in a Medieval Cathedral Play', Thomas Forrest Kelly (ed.), Plainsong in the Age of Polyphony (Cambridge, 1992), 65-99; Dunbar H. Ogden, 'The Staging of The Play of Daniel in the Twelfth Century', Ogden (ed.), Play of Daniel, 11-32; and Richard K. Emmerson, 'Divine Judgment and Local Ideology in the Beauvais Ludus 
Danielis', Ogden (ed.), Play of Daniel, 33-61. For a history of modern performances of this most popular of all Latin music-dramas, beginning with Noah Greenberg's pioneering 1958 production at the Cloisters, see Fletcher Collins, Jr., 'The Play of Daniel in Modern Performance', Ogden (ed.), Play of Daniel, 63-75. Numerous sound recordings are available, including the classic version by New York Pro Musica, directed by Noah Greenberg (Decca DL 9402, 1958).

3 For a succinct overview of the debate about the relationship between the two plays, see Emmerson, 'Divine Judgment and Local Ideology in the Beauvais Ludus Danielis', 39 and 57 (n 29). Wulstan attempts to put the long controversy about priority and influence to rest by arguing that both works derive independently from a lost prototype associated with the 'School of Abelard' at Laon; see 'Liturgical Drama and the "School of Abelard", Comparative Drama 42 (2008), 347. Similarly, Fassler understands the two works as 'independent attempts to accomplish the same end allowing for popular elements of the Feast of Fools to be present through dramatizing a particular Old Testament story'; see 'The Feast of Fools and Ludus Danielis', 87.

4 Young, Drama of the Medieval Church, 2.290 (3). For other editions and translations, see $\mathrm{n} 2$.

5 Peter Damian-Grint, 'Hilary', H.C.G. Matthew and Brian Harrison (eds), Oxford Dictionary of National Biography, 61 vols (Oxford, 2004), 27.87-8 succinctly reviews the meager information about the life of Hilarius (occasionally referred to as Hilarius of Orléans or Hilarius of Angers). Earlier and less reliable accounts appear in Thomas Wright, Biographica Britannica Literaria, or, Biography of Literary Characters of Great Britain and Ireland: Anglo-Norman Period (London, 1846), 91-4; Henry Morley, English Writers: An Attempt Towards a History of English Literature, 11 vols (London, 1887-95), 3.104-13; Champollion-Figeac, Hilarii versus et ludi, v-xv; Fuller, Hilarii versus et ludi, 10-16; and Young, Drama of the Medieval Church, 2.211. For a highly speculative biography, see Werner Robl, Der Dichter und Lehrer Hilarius von Orléans: Auf den Spuren eines Abaelard-Schülers (Neustadt, 2002). In his self-published narrative, Robl argues that Hilarius was born in Orléans around 1080 and died in Paris sometime after 1162.

6 Damian-Grint, 'Hilary', 88.

7 Hilarius, 'Ad Petrvm Abaelardvm', Bulst and Bulst-Thiele (eds), Hilarii Aurelianensis Versus et Ludi, 31 (11 and 31-5). All translations in the text and notes are mine unless otherwise noted.

8 Nikolaus M. Häring, 'Hilary of Orléans and His Letter Collection', Studi medievali, ser 3 (1973), 1071-122; Bulst and Bulst-Thiele, Hilarii Aurelianensis Versus et Ludi, 15-18, 81-95. 
9 Bevington, Medieval Drama, 155. William Smoldon plausibly argues that Hilarius must already have settled into his established life as a canon before composing his play:

I cannot think that, if and when Hilarius managed to get his work performed, he would still have been a goliard. The resources demanded for this considerable dramatic production ... would surely call for the approval and support of a fairly important ecclesiastical authority, one likely to have little time for people belonging to the free-and-easy world of the wandering scholar.

See Smoldon, The Music of the Medieval Church Dramas, 266. On the other hand, Wulstan notes that the dissemination of distinctive melodic patterns across Europe suggests that the paraliturgical repertory was transmitted by wandering scholars, 'whose notoriety was not always deserved'; see 'Liturgical Drama and the "School of Abelard"', 350.

10 The codex is catalogued as ms lat. 11331. For codicological and paleographical descriptions of the manuscript, see Champollion-Figeac, Hilarii versus et ludi, v-xiv; Fuller, Hilarii versus et ludi, 3-6; and Bulst and Bulst-Thiele, Hilarii Aurelianensis Versus et Ludi, 68. A black-and-white photographic reproduction of the opening lines of the Play of the Image of St. Nicholas (f 11r) is reproduced by Young, Drama of the Medieval Church, 2.Plate XXII.

11 A sixteenth piece, a short, unimaginative prose allegorization of the word Jerusalem that is the final entry in the manuscript, appears in a different hand from that of the rest of the codex; no one assigns this piece to Hilarius. See Bulst and Bulst-Thiele, Hilarii Aurelianensis Versus et Ludi, 68.

12 See Thomas Stehling (ed. and trans.), Medieval Latin Poems of Male Love and Friendship, Garland Library of Medieval Literature 7 (New York, 1984), 68-75, and Therese Latzke, 'Die Ganymed-Episteln des Hilarius', Mittellateinisches Jahrbuch 18 (1983), 131-59.

13 For editions and translations of the plays, see $\mathrm{n} 1$.

14 Young, Drama of the Medieval Church, 2.211. On the diverse nature of the manuscript's contents, see n 54 .

15 Paul Marchegay, 'Charte en vers de l'an 1121, composée par Hilaire, disciple d'Abailard et chanoine du Ronceray d'Angers', Bibliothèque de l'École des Chartes 37 (1876), 245-52 and Paul Marchegay, Cartularium monasterii beatae Mariae Caritatis Andegavensis, Archives d'Anjou 3 (Angers, 1854), 168-9, 284-7, and 347. The text of the poem has been edited by Bulst and Bulst-Thiele, Hilarii Aurelianensis Versus et Ludi, 61-4. See also Therese Latzke, 'Zum "Iudicium de calumnia molendini Briesarte" und zu den vier Nonnenepisteln des Hilarius', Mittellateinisches Jahrbuch 16 (1981), 73-96. The nature of Hilarius's relationship with the Benedictine nuns 
at Notre-Dame la Charité would be well worth knowing. Founded in 1028 by Fulk Nerra, count of Anjou, and his wife Hildegardis, it soon became one of the wealthiest and most influential institutions of its kind, the greatest foundation in Angers after the cathedral. Although 'the abbey of Ronceray was part of a system of luxurious outdoor relief which the church had been obliged to provide for surplus daughters of the nobility of France', it nevertheless faced a severe economic crisis around the time of Hilarius's residence in Angers. See John McManners, French Ecclesiastical Society under the Ancien Régime (Manchester, 1960), 91, and André Chédeville, 'Au debut du XII ${ }^{\mathrm{e}}$ siècle: les moniales du Ronceray d'Angers face aux réalités économiques', Sylvain Gougueheim (ed.), Retour aux sources: Textes, études et documents d'histoire médiéval offerts à Michel Parisse (Paris, 2004), 227-37. The abbey is still largely intact and is regarded as one of the jewels of eleventh- and twelfth-century architecture.

16 Because of its accuracy and widespread availability, I have chosen Karl Young's 1933 edition as the base text for this study and translation. I reference line numbers in my translation parenthetically throughout this introduction; the stanzaic forms and line numbering of the translation follow Young's edition. I have also consulted the more recent but far less accessible edition of Hilarius's complete works by Walther Bulst and M.L. Bulst-Thiele (1989). For a complete list of editions, see n 1. All biblical citations are from the Douay-Rheims translation of the Vulgate bible. Unless otherwise noted, all other translations are my own.

17 The incipit reads: Historia de Daniel Representanda [The Story of Daniel for Performance]. For the hour of performance, see 336.1-5. Sepet and Chambers have suggested that the play had no necessary connection with the liturgy, but this argument is completely untenable; see Marius Sepet, Les Prophètes du Christ: Étude sur les origines du théâtre au Moyen Age (Paris, 1878; rpt Geneva, 1974), 59-61, and E.K. Chambers, The Mediaeval Stage, 2 vols (London, 1903), 2.58.

18 Arlt, Ein Festoffizium des Mittelalters aus Beauvais in seiner liturgischen und musikalischen Bedeutung; Young, Drama of the Medieval Church, 2.303; Fassler, 'The Feast of Fools and Ludus Danielis', 66-7 and nn 5 and 6.

19 Fassler, 'The Feast of Fools and Ludus Danielis', 66-7. For evidence of suitable occasions for the insertion of the play into the liturgy, see 336.1-5.

20 For the Latin text and an English translation, see the Appendix to the following translation.

21 Young, Drama of the Medieval Church, 2.34-6, 59-63, 99-100.

22 See n 52.

23 Axton, European Drama of the Early Middle Ages (London, 1874), 84. 
24 Young, Drama of the Medieval Church, 2.288. See also Wilhelm Creizenach, Geschichte des neueren Dramas, 2nd edn, 3 vols (Halle, 1911; rpt New York, 1965), 1.72-3, and Fuller, Hilarii versus et ludi, 45.

25 Grace Frank, The Medieval French Drama (Oxford, 1954), 55. For similar praise, see Smoldon, The Music of the Medieval Church Dramas, 223.

26 For a convenient table of the metrical forms that occur in the play, see Bulst and Bulst-Thiele (eds), Hilarii Aurelianensis Versus et Ludi, 77. In this respect as in many others, Hilarius's play resembles the Beauvais Ludus Danielis, which contains more than fifty melodies 'distributed roughly according to the principle "new speaker, new tune"'; Axton, European Drama of the Early Middle Ages, 84.

27 Smoldon, The Play of Daniel, 4. For Smoldon's argument that the extant text is 'surely a later copy of a music-provided original', see The Music of the Medieval Church Dramas, 223. Mathias Bielitz, 'Bemerkungen zur Musik des Daniel-Spiels von Beauvais', Bulst and Bulst-Thiele (eds), Hilarii Aurelianensis Versus et Ludi, 120-79, provides detailed analysis of the music in the Beauvais Ludus Danieli.

28 Du Méril, Origines latines du theâtre moderne, 241.

29 Fuller, Hilarii versus et ludi, 42-3.

30 Young, Drama of the Medieval Church, 2.288-9; Sepet, Les Prophètes du Christ, 63; Chambers, The Mediaeval Stage, 2.58; Axton, European Drama of the Early Middle Ages, 84; Wulstan, 'Liturgical Drama and the "School of Abelard"', 49.

31 Young, Drama of the Medieval Church, 2.289.

32 Bulst and Bulst-Thiele, Hilarii Aurelianensis Versus et Ludi, 9, are convinced that the entire work is by Hilarius himself, noting the uniform quality of the verse and its consistency with the other poems in the manuscript. The use of multiple stanzaic forms does not constitute evidence for multiple authorship, especially in the case of a poet as accomplished and prolific as Hilarius. See Fuller, Hilarii versus et ludi, 40-3.

33 Karl Young, Ordo prophetarum (Madison, WI, 1922), 41. For other depictions of Daniel as a young man, see Fassler, 'The Feast of Fools and Ludus Danielis', 93 and nn 89-91.

34 Young, Drama of the Medieval Church, 2.289, and Axton, European Drama of the Early Middle Ages, 85.

35 Because the reference to stringed instruments occurs in the text of the play rather than in a rubric, it is possible that it is a mere trope rather than an indication of performance practice. The critical consensus nevertheless has been that the multiple mentions of harp-playing in the Beauvais Ludus Danielis point to the use of actual musical instruments (Young, Drama of the Medieval Church, 2.291, 293, 296; 11 43,96 , and 244), a notion confirmed by a stage direction that explicitly calls for 
the citharistae to perform for the king (Young, 2.296; 215sd). See Axton, European Drama of the Early Middle Ages, 84.

36 Bevington, Medieval Drama, 155.

37 Young, Drama of the Medieval Church, 2.287. On the basis of a comparison with the joyful tripudium of the Beauvais Ludus Danielis, Fassler arrives at the same conclusion with respect to the lively staging of this scene': 'While they sing, it may be assumed that the other members of the king's court behave in Babylonian mode'; see 'The Feast of Fools and Ludus Danielis', 88, n 82.

38 The analogous stage direction in the Beauvais Ludus Danielis is somewhat more informative than Hilarius's rubric: 'And immediately an angel holding a sword shall threaten the lions lest they touch him [Daniel]'. See Young, Drama of the Medieval Church, 300 (351sd).

39 Hilarius underscores the thematic contrast between the false kings of the world and the true king of kings at several points in the play; see, for example, 43-6, 241-6, 331-6, and 336.1-5, and the hymn translated in the Appendix. For a discussion of the Babylonian and Persian kings as antitypes to the coming of Christ the king, see Glynne Wickham, 'Stage and Drama till 1660', Christopher Ricks (ed.), English Drama to 1710 (London, 1971), 30. Emmerson reassesses the theme of kingship in the Beauvais Ludus Danielis by arguing that the work serves to define the proper relation between sacred and secular authority, inasmuch as it supports the theocratic ideology of the bishop-counts of Beauvais as opposed to the growing hegemony of the monarchy and the Parisian capital; see 'Divine Judgment and Local Ideology in the Beauvais Ludus Danielis', 39-53. For a discussion of the Ludus Danielis as a 'systematic and pervasive critique of secular authority that powerfully condemns both the institution of monarchy and its representatives', see Constantine T. Hadavas, 'Questioning the Role of Civil Authority in the Ludus Danielis', David J. Perry (ed.), The Story of the Prophet Daniel, 147-62.

40 See $\mathrm{n} 41$.

41 See Louis Réau, Iconographie de l'art chrétien, 3 vols in 6 (Paris, 1955-59), 2: 402-3; Gertrud Schiller, Iconography of Christian Art, Janet Seligman (trans.), 2 vols (Greenwich, CT, 1971-2), 2.19; Elizabeth Saxon, The Eucharist in Romanesque France: Iconography and Theology (Woodbridge, Suffolk, 2006), 108-9, 187; and Emmerson, 'Divine Judgment and Local Ideology in the Beauvais Ludus Danielis', $35-7$ and 56 (n 21).

42 Commentators note that dietary laws go back to the oldest periods of Israelite history. 'Since Daniel and his companions believed that with good conscience they could eat only vegetables (literally, "seed-bearing plants"), it seems that they feared that any meat or fish they received as royal rations might include forbidden species 
or might have been prepared in an "unclean" way'. See Louis F. Hartman and Alexander A. Di Lella (eds), The Book of Daniel, Anchor Bible 23 (Garden City, NY, 1978), 133.

43 For a discussion of the thematic, stylistic, and lexical similarities of the two biblical episodes, see Hartman and Di Lella, The Book of Daniel, 186.

44 Hilarius's treatment of Darius as 'furious' (267.1-2, 298.1) differs markedly from the depiction of the conscience-stricken king in the biblical account.

45 Walter Cahn, Romanesque Bible Illumination (Ithaca, NY, 1982), 154; Réau, Iconographie de l'art chrétien, 2.402; Schiller, Iconography of Christian Art, 2.26; Saxon, The Eucharist in Romanesque France, 101, 107-11, 239-40; Fassler, 'The Feast of Fools and Danielis Ludu', 95.

46 Saxon, The Eucharist in Romanesque France, 110.

47 See, for instance, the half-page illumination to the Book of Daniel in a tenth-century bible (Léon, Real Colegiata de San Isidoro, Cod. 2, f 325v), reproduced by John Williams, 'The Bible in Spain', John Williams (ed.), Imaging the Early Medieval Bible (University Park, PA, 1999), 210-12 and fig. 18.

48 See, for instance, the Michaelbeuern Bible, which, like the play by Hilarius, dates from the second quarter of the twelfth century (Michaelbeuern Stiftsbibliothek, Cod. Perg. 1, f 191r), where Habakkuk carries a loaf of bread and a spherical vessel; reproduced in Cahn, Romanesque Bible Illumination, 156, illustr. 113. In an early twelfth-century Tuscan Bible (Florence, Biblioteca Medicea Laurenziana, Edili 125, f 259v), Habakkuk carries the bowl before him while a separate bread basket hangs from the staff on his shoulder; see Cahn, Romanesque Bible Illumination, 152, illustr. 110. Similarly, a late eleventh-century carved capital at Ste-Radegonde in Poitiers depicts Habakkuk carrying an unbroken loaf in the form of a host; see Saxon, The Eucharist in Romanesque France, 170. A miniature from a French copy of Jerome's Commentary on Daniel (Dijon, Bibliothèque Municipale Ms 132, f 2v) that also dates precisely from the time of Hilarius (ca 1125-35) shows Habakkuk carrying a flat host-like disk of bread and a separate wine flask; see Walter Cahn, Romanesque Manuscripts: The Twelfth Century, 2 vols (London, 1996), 1.Plate 15; 2.79.

49 Saxon, The Eucharist in Romanesque France, 108-9.

50 Ibid, 171.

53 See n 41.

54 Orléans, Bibliothèque Municipale ms 201, ff 176-243. The Fleury De Sancto Nicolao et de Iudeo and the Resuscitatio Lazari have been edited by Young, Drama of the Medieval Church, 2.199-208 and 2.344-8. For English translations, see Fletcher Collins, Jr. (ed.), 'The Image of St. Nicholas (Iconia Sancti Nicholai)' and 'The Raising of Lazarus (Resuscitatio Lazari)', Medieval Church Music-Dramas: A Repertory of 
Complete Plays (Charlottesville, 1976), 189-239 and 335-62. For a very brief comparison of Hilarius's plays with those from Fleury, see Thomas P. Campbell, 'Augustine's Concept of the Two Cities in the Fleury Playbook', Thomas P. Campbell and Clifford Davidson (eds), The Fleury Playbook: Essays and Studies, Early Drama, Art, and Music Monograph Series 7 (Kalamazoo, MI, 1985), 89-92. As a useful starting point, C. Clifford Flanigan makes a crucial distinction between the underlying organizational principles of the Fleury manuscript and that containing the works of Hilarius:

Thus the dramas [of Hilarius] are part of a larger literary corpus of works by a single scholar-poet. Unity of authorship is the principle that accounts for the placing of these plays with the non-dramatic materials...[T]he Fleury manuscript contains only plays, while...in the Hilarius manuscript the dramas are part of a larger literary collection. The redactor - unlike the Fleury redactor - apparently believed that music-drama belonged generically with lyric poetry in a category consisting of sung and performable texts.

See Flanigan, 'The Fleury Playbook, the Traditions of Medieval Latin Drama, and Modern Scholarship', Campbell and Davidson (eds), The Fleury Playbook, 9-11. 


\section{Translation}

Because of its accuracy and widespread availability, I have chosen Karl Young's edition as the base text for this translation; see Drama of the Medieval Church (Oxford, 1933), 2.276-86. The stanzaic forms and line numbering of the translation follow his edition. I have also consulted the excellent but far less accessible edition of Hilarius's complete works by Walther Bulst and M.L. Bulst-Thiele (eds), Hilarii Aurelianensis Versus et Ludi; Epistolae; Ludus Danielis Belouacensis, Mittellateinische Studien und Texte 16 (Leiden, 1989), 48-59. For a complete list of editions, see note 1 to the Introduction. As a rule, I have tried to keep this translation as faithful to the sense, tone, and rhythm of Hilarius's poetry as possible while not sacrificing fluency or readability. In the interest of fidelity to what the poet wrote, however, I have at times retained certain awkward constructions such as Hilarius's use of the future perfect tense in stage directions or his predilection for the passive where the modern reader would expect the active voice. Unless otherwise noted, all biblical citations are from the Douay-Rheims translation of the Vulgate bible.

\section{The Story of Daniel for Performance}

In the first part of this [play], these persons are necessary:

A King for the role of Belshazzar*

The Queen

Daniel

Four Soldiers

Four Elders

But for the second part [of the play]:

A King for the role of Darius

a.1 [All three of Hilarius's surviving plays are preceded by a list of the necessary dramatis personae. MS Baltasar follows the Vulgate spelling of the name of the Babylonian king. I have preferred the more familiar spelling of the Authorized Version (Belshazzar) throughout. 
The same Daniel

The Soldiers and Elders who were in the first part

An Angel in the lions' den

Habakkuk $^{*}$

Another Angel who carries Habakkuk down to the [lions'] den

A third Angel who sings 'I bring you tidings [from on high]'.

\section{First of all, after Belshazzar will have entered with his procession and will have seated himself upon his throne, the Soldiers will sing this song before him:*}

Let all those of one mind repeatedly echo the applause of the people

And let them sing of the power of the brilliant prince!

We must worship his sceptre most devoutly,

for it extends far and wide over land and sea;

him whose father could boast over his enemy,

plundering the vessels of the Lord from the altar;

he who struck down Jerusalem with his deadly sword

and led away those miserable people in a triumphal procession.*

And you who are the highest prince and son of the victor,

a.10 MS Abacub varies slightly from the Vulgate spelling Abacuc. I have preferred the more familiar spelling of the Authorized Version (Habakkuk) throughout.

0.1-2 At twelve locations in the margins of the text, four different male names are written in a later scribal hand and crossed through with a red line. The name Iordanus first occurs here and at 156, 203.1, and 330.1. The name Hilarius occurs five times (76, 176, 213, 267.1, and 286.1), Simon twice (238.1 and 275.1), and Hugo once (52).

2 Max Harris speculates that the entry procession may have been accompanied by actual rhythmic clapping by the players or spectators; see Sacred Folly: A New History of the Feast of Fools (Ithaca NY, 2011), 118. Compare to Ps. 46:2 and the second conductus from the Beauvais Ludus Danielis.

3 The 'sceptre' could refer figuratively to Belshazzar's rule, but it seems likely that a literal object is meant as well. Margot Fassler, 'The Feast of Fools and Ludus Danielis: Popular Tradition in a Medieval Cathedral Play', Thomas Forrest Kelly (ed.), Plainsong in the Age of Polyphony (Cambridge, 1992), situates both Hilarius's play and the Beauvais Ludus Danielis within the context of the feast of the Circumcision (1 January) and interprets line 3 as a possible reference to the carnivalesque activities associated with that occasion. If Fassler's speculation is correct, then the playful misuse of the cantor's rod would provide an appropriate thematic parallel to Belshazzar's misappropriation of the vessels plundered from the Temple.

8 The allusion is to Nebuchadnezzar (ca 634-562 BCE, reigned 605-562 BCE), Belshazzar's father, who captured Jerusalem in $597 \mathrm{BCE}$, plundered the Temple, and forced the Jews into exile in Babylon. Compare to Dan. 5:2 and to 15-18 and 27-30 below. 
we do not believe you to be of lesser power,

you whose judgment is looked upon with trembling,

you who are praised highly with harps and harmonious voices;

you who, following the example of your father in all things,

subjugate the rebellious with the might of your power.

When they have done this, the King will say to his Soldiers:

Let the vessels of the sanctuary

be brought forth to serve our meal,

the ones that my father got

when he destroyed Jerusalem.

Then the soldiers, carrying in the vessels, will sing in this way:

Let us rejoice today

in royal majesty;

the many nations tremble

before the might of his power!

Here is the one whose power

conquers those who rebel!

Here is the one whose power

is feared by those who dwell in Asia!

So that his father's triumphs

might be remembered,

here you might gaze upon

the spoils of Jerusalem!

Here is the one whose power

conquers those who rebel!

Here is the one whose [power

is feared by those who dwell in Asia!]

The enemy is conquered by you

and the world is terrified;

just as it was first subject to your father,

12 This line probably indicates that actual stringed instruments were used in performance. 
so now it is subject to you.

Here is the one whose power

[conquers those who rebel!

Here is the one whose power

is feared by those who dwell in Asia!]

We compare you to your father

and as the greatest king of kings*

you are the most vigorous heir,

and we believe you are a god.

Here is the one whose power... .

$$
\text { and so forth. }
$$

Afterwards, a right hand will appear above the head of the King, writing: 'Mane, Techel, Phares'. When he has seen this, the King will be deeply disturbed and he will say to his soldiers:

Seek out as quickly as possible

the wise men of this realm,

those who can explain

what the meaning of this writing is.

Then four men will come, to whom the King will say:

Wise men of Babylon,

since you are so learned,

tell me if you can

the meaning of my vision

and what this writing might say.

I saw a certain hand that

wrote something I do not know,

it appeared to move by itself

and then it was no longer possible

to see that right hand.

The hand that wrote moved by itself;

44 Ironically, the term 'king of kings' occurs once in the Hebrew bible when Daniel applies to Nebuchadnezzar: 'Thou art a king of kings: and the God of heaven hath given thee a kingdom, and strength, and power, and glory' (Dan. 2:37). For Christian readers, 'king of kings' was a title reserved solely for Jesus based on its use in 1 Tim. 6:15 and Rev. 17:14 and 19:16. 
but I cannot tell what it wrote.

If you can read this inscription

and expound what it means,

I will give you great rewards.

And so the four Elders will move off to one side, and returning after a short while they will say to the King:

We cannot interpret for you

either the writing of the right hand

or the meaning of the inscription.

Then the King will say for all to hear:

And so let the entire realm know

what is to be done at my command:

whoever will interpret this more clearly,

let him be honored with a golden necklace

and a purple robe, and be

the third man in the kingdom with me.

While the Queen is entering in order to confer with the King, the four Soldiers preceding her will sing:

Hail, O royal spouse, surpassing all others, whose supreme wisdom understands all hidden things, you are the glory of all women;

therefore come to the palace of the King so that your marvelous knowledge might be revealed in the presence of our prince.

Come quickly, so that you may offer your advice

to your husband.

O you who alone are

without a flaw among all women,

and at whose eloquence

the mind of the wise ones is amazed,

you are worthy to be the partner of the King; 
for indeed your talent should be marveled at, you who alone can command him;

therefore to console the troubled king come quickly

so that you may offer your advice

to your husband.

When she comes before the King, she will say:

Do not be upset, Belshazzar, because of this sudden vision, for Daniel is here, to whom nothing is unknown.

In this man, as we well know,

is the spirit of the gods,

and we have seen many things

that he prophesied before.

Command, O King, that Daniel be questioned, by whom this difficult inscription might be explained.

\section{Then the King [will say] to his Soldiers:}

Attendants, therefore seek out Daniel so that I might consider his advice to me.

Leading Daniel in, the Soldiers will sing thus:

Let all sadness be gone today,

for now joy is near at hand.

Thanks are given to Daniel

whose wisdom,

whose prescience of the future,

knows all hidden things;

to whom events of the future

are as certain and well known as the past;

he who will interpret

the astonishing vision of the King.

The King has promised countless gifts,

high office, a purple [robe], and other such things

to the one who will explain this writing.

But in Babylon

there are no such wits 
who can discern these mysteries.

Therefore an assembly will present him

at the palace of the King,

the one who without a doubt

will now explicate the King's vision.

After that, the King will say to Daniel:

If the things that we have heard are true,

the vision that we have seen will be made clear;

for the spirit of the gods is in you,

because you know everything by divine inspiration.

Therefore do not delay to unravel

what the meaning of this writing is;

if you should wish to explain it to me,

you will soon become a very wealthy man.

\section{Daniel [will say] to the King:}

My lord, do not worry about the reward;

for I will reveal these wonders for free.

You have the vessels of God for your own enjoyment,

but because of that He will destroy you.

The writing that you ask about bears witness to this

because 'Mane': you will not be king tomorrow.

'Techel' means your reign has been weighed

and is found to be wanting.

Finally, 'Phares' declares that it is already divided;

it is well known that this has been foreseen by the Lord.*

Then the King, dressing [Daniel] in his most beautiful robes and making him like unto himself, will say:

The one who has explained this writing to us will receive a purple [robe] as I had promised,

145 Dan. 5:26-28: 'MANE: God hath numbered thy kingdom, and hath finished it. TECHEL: thou art weighed in the balance, and art found wanting. PHAREs: thy kingdom is divided, and is given to the Medes and Persians'. 
and he may sit at the right hand of the prince;

because of his ability

he will also govern with me

over one third of my kingdom.

And having turned back toward his Soldiers, he will say:

Because of the prophecy of this true prophet

it is fitting that the vessels be removed from our sight;

I will not hold these vessels in contempt as I did before;

I do not wish that they should cause me such a great disaster. ${ }^{*} 155$

And so the Soldiers, carrying the vessels away and leading the Queen back out, will sing:

Rejoice, royal spouse,

the glory of Babylon,

you who surpass all others

are the indispensable lady

for the King.

You whose wisdom gives

counsel to the King,

and by giving comfort

you surpass the multitude

of women.

Upon whose counsel

the entire realm depends,

and because of your vast understanding

the assembly joyfully

praises you.

Your praise is threefold:

beauty, modesty, reason,

which are far superior to anyone else;

you are worthy of this

royal partnership.

155 Belshazzar's change of heart is a striking departure from the biblical text where the king rewards Daniel for his service but is then slain by Darius that same night; cf. Dan. 5:30-1. 
After this, Darius, the king of the Persians and the Medes, enters with his army and acts as if he is killing Belshazzar and takes the crown for himself, and he will place it on his own head. * And when he will have seated himself upon his throne, this song of praise will be sung before him:

Because it is right for us to be joyful

in your honor, Darius,

therefore with like minds

let us rejoice;

we will offer to you the praise that we owe!

Whose yoke the Persians fear

and also all the other nations,

because both the greatest and the least

are everywhere subject to him,

let us rejoice;

we will offer to you the praise that we owe!

Whoever does not agree with him

feels his wrath abundantly;

because this king is so powerful,

let us rejoice;

we will offer to you the praise that we owe!

Upon whose kingdom rely

both neighbouring and distant lands;

and so standing by the king,

recalling the deeds of the king,

let us rejoice,

we will offer to you the praise that we owe!

Afterwards, his closest advisors tell him about the wisdom of Daniel:

King more mighty than any prince,

command that that most learned

Daniel be sought out;

we have learned that he is wise

175.1-4 Dan. 5:31 reports that Belshazzar was overthrown by 'Darius the Mede', although no such person is known in either the Persian or Babylonian historical record. Attempts have been made to identify Darius the Mede as Cyrus II of Persia (ca 600 or 576 BCE-530 BCE) and Darius the Great (reigned 522-486 BCE). 
and we know that he was very dear

to Belshazzar.

\section{The soldiers say to the People:*}

Let the princes who are in the court hear

what the royal power has ordered to be done,

and let them not disdain the commandments of the King.

There is a man without equal in Babylon

who, standing above all others through his amazing knowledge, predicted to Belshazzar the division of his kingdom.

Therefore, we have asked for his judgment;

let him be sought out so that he might enter our palace, so that he might be a confidant to the King in all matters.

Then the ones who will lead Daniel in will sing thusly:

Let thanks be given

to Daniel today,

to whose wisdom

all things are known!

The spirit is present in him

by which he foretells all things,

both the distant future

as well as present things.

By means of his knowledge

the King will reign more safely.

Therefore we lead him

to the palace of the king,

the man who we believe

will bring relief to us.

203.1 Speeches addressed directly to the audience, drawing the worshippers directly into the imagined world of the performance, were conventional in medieval Latin and vernacular drama; see 318.1 below.

222 On the basis of the stanzaic form, two lines are missing from this passage. Bulst and BulstThiele, Hilarii Aurelianensis Versus et Ludi, 55, and Fuller, Hilarii versus et ludi conjecture that the missing lines preceded 221, while Du Méril, Origines latines du théatre moderne, places the loss after 222 . 
When Daniel will be standing before the King, the King will say to him:

Your wisdom,

which knew hidden things,

is praised today

in my presence.

If you give me

useful advice,

I will give you realms

to be ruled under your power.

\section{And Daniel [will say] to him:}

I am not greedy for your gifts, $O$ Prince,

but if something can be done for you

through my service, hear what I say:

it will be done freely and without cost.

Then the King will make him sit beside him. The Envious Ones, seeing him in friendship with the King and wishing him to be an enemy of the King, but not finding any reason except in the law of his God, coming to the King, will say:

Command, O King, that the decrees

that the noble princes have given be observed.

The first principle in the decrees is held to be

that no god be worshipped except you. ${ }^{*}$

You alone are god above the gods,

you who rule the peoples and the Chaldeans.

It is fitting that you alone be worshipped,

while you watch over the people and the realms.

242 The corresponding biblical passage states that the law forbids anyone to make a petition to any god except the king for a period of thirty days (Dan. 6:13). Hilarius has altered his source in order to provide a clear echo of the first commandment of the Decalogue (Exod. 20:3 and Deut. 5:7). The mistaken ascription of divine status to Darius (241-4) parallels a similar misapprehension with respect to Belshazzar; see 44-6.

244 The Chaldeans were renowned for their abilities as astrologers and soothsayers; compare to Dan. 5:7. See Louis F. Hartman and Alexander A. Di Lella (eds), The Book of Daniel, Anchor Bible 23 (New York, 1978), 129. 
If anyone should seek any protector but you,

he will be thrown beneath the claws of the lions.

\section{And the King will say:}

These are my commands:

all things that the court has decreed

will be firmly settled.

Then Daniel, going away in secret, will pray to his God. When he has been seen, the Envious Ones will say to the King:

O King, to whom the Babylonian realms are subject, the laws that the court has decreed are useless;

for it decreed that you be worshipped

like the celestial deities for a period of thirty days,

and if anyone were to disregard these royal commandments, he would justly experience the companionship of the lions.

\section{And the King will add:}

Truly, it has been ordered that I be feared as a god and that my divine power be exalted by all men.

The Envious Ones [will say] to him again:

We have seen Daniel

prostrate before his gods.

Let him be given as food to the lions

because he scorned

what King Darius of Babylon

has decreed.

\section{The King [will say] to them:}

If he refuses to obey the law that I have set forth, let him feel the wrath of the lions as he has deserved. 
They lead Daniel to the [lions'] den. Then the furious King, coming before him, will say as consolation:*

Let not the servant of God despair

because this punishment is given to him;

but let him trust in his God

that the lion will spare him.

And Daniel, entering the den, will pray thus:

God of the earth, God of heaven,

I commend myself to you alone;

send a protector to me,

that he might deliver me from this calamity.

Then the Angel of the Lord will appear in the den, carrying a sword, and he will shut the mouths of the lions. Afterwards, another Angel will come to Habakkuk, who is carrying dinner to his reapers, and the Angel will say to him:*

Habakkuk, I bear a message from heaven;

because you have a dinner for Daniel,

267.1-2 Young astutely notes that the play departs from the biblical account in its depiction of Darius as a 'rex iratus' here and at sd after 298. In Dan. 6:14-20, the king condemns the prophet with great reluctance, worries about how to rescue him, prays for his safety, spends a sleepless night, and in the morning cries to Daniel 'with a lamentable voice'. Young plausibly concludes that the shift in characterization 'reflects the influence of the angry Herod of the Epiphany plays'; see Drama of the Medieval Church, 2.287-8. However, an anonymous correspondent has pointed out that the king is twice described as 'iratus rex' when he learns of Daniel's mockery of Bel and his success at tricking the priests (Dan. 14:7 and 14:19). Perhaps the irate monarch from Dan. 14 was conflated with Darius from Dan. 6 in the same way that the lions' den and Habakkuk episode from Dan. 14 was conflated with the lions' den of Dan. 6. At any rate, in Hilarius's version, the irate king's 'consolation' must be read as sarcastic both here and at 299-302.

275.1-3 The story of Habakkuk, seized from his fields in Judea by an angel and miraculously transported to the lions' den in Babylon is found in the deuterocanonical narrative known as 'Bel and the Dragon'. In the Vulgate Bible, the chapter is designated as Dan. 14. Like his anonymous counterpart who composed the Beauvais Ludus Danielis, Hilarius has interpolated the Habakkuk episode (Dan. 14:32-8) into the story as it is recounted in Daniel 6. The conflation of the two parallel stories of Daniel in the lions' den was common throughout the middle ages. 
go, carry it to Babylonia,

to the one whom the ferocity of the lions does not injure.

Answering, Habakkuk will say:

God knows that I do not know that den

nor do I have any knowledge of that place.

Truly, the Angel will lead him to the den by the hair, and when he is standing next to Daniel, he will say:

O good man, whom God loves,

and whom the wrath of the lions has not touched,

now God chooses you upon the earth;

therefore take what he sends to you,

dear brother.

Then Daniel, giving thanks to God, will say:

Now it has been revealed

that the Lord

has desired to rescue me,

He who considered it worthy

to grant this food

by a messenger.

Nay, he also

restrained

the ferocity of the lions;

for he assigned

an angelic guardian

as was fitting.

Darius, furious, will visit Daniel, saying:

O good man, why do you think

that your God was able

to deliver you from the lion,

the God whom you do not cease to worship?

And Daniel [will say] to him:

My God 
sent me

a good protector,

through whom

the roarings of the lions

have truly ceased.

The King will add:

Therefore because he has not sinned,

let the just man be brought forth;

but whoever has accused the just man,

let him be thrust down within.

Then the Envious Ones will be put into the den so that they might be devoured by the lions. Afterwards, the King, taking Daniel by the hand, will lead him to his throne and make him sit beside him. Then he will say to his Soldiers:

Let it be proclaimed

that the Lord of Daniel

should be worshipped;

and that if the decree

should be spurned,

let it be avenged without delay.

And [the Soldiers will say] to the People:

May you listen

and not reject

what has been ordered by the King;

he commands that

the king of the heavens be worshipped,

by whom all things were made.

The King will desire

that if anyone be so rash

as not to worship,

let him know that he

condemns himself to perish

as Darius has commanded.

Then Daniel will prophesy in this manner: 
Let the faithful assembly rejoice today; confusion presses upon the kings of Judea.

The Lord will be born in whose empire government will cease and the anointing of kings; whoever will believe in him with King Darius, he will be repaid with eternal joy.

\section{And then the Angel will appear, singing in a loud voice: I bring you tidings... .* and so on. When this has been done, let Darius begin the Te Deum laudamus if this will be performed at Matins, but if it is for Vespers, Magnificat anima mea Dominum.}

336 Lines 331-6 depart from the biblical account. Daniel's prophecy is rooted in the tradition of the Ordo Prophetarum, a liturgical practice for Christmas day and its octave. that consists of short passages spoken by a sequence of prophets concerning the coming of Christ. The passage assigned to Daniel in several extant versions reads as follows: 'Sanctus sanctorum veniet, et unctio deficiet' [The Holy of Holies will come, and anointing will fail]. The sense of Hilarius's poetic paraphrase of this prophecy is that when Christ the King is born, earthly kingdoms will come to an end. (See also n 41 to the Introduction.) It is not insignificant that the Beauvais Ludus Danielis concludes with a similar passage. The irony inherent in the prophecy is that the reign of Christ will put an end not only to pagan kingdoms like those of Nebuchadnezzar, Belshazzar, and Darius, but also to the nation of the Jews.

336.1 The term 'alta voce' can signify either a loud or a high-pitched voice. As the first line of the hymn suggests, it is probable that the angel actually appeared 'on high' somewhere in the sanctuary. The Beauvais Ludus Danielis also concludes with an angel who sings the first stanza of the Nuntium vobis fero, followed by a group of cantors chanting the Te Deum. The four-stanza Nativity hymn, attributed to Fulbert of Chartres (d. 1028), also appears at the conclusion of a brief quasi-dramatic Christmas ceremony of uncertain date from Limoges, in a twelfth-century Officium Stellae from Sicily, and in a thirteenth-century ceremony for the feast of the Epiphany from Padua. For the full Latin text and my English translation, see Appendix.

336.2-3 The Te Deum and the Magnificat are two of the most venerable hymns of the Church.. The Te Deum was traditionally sung after the last responsory at Matins, as a processional chant, and on other special occasions to express strong emotions of thanksgiving. The Magnificat (Canticle of the Blessed Virgin Mary) originated as the song of praise sung by the Virgin at the Visitation (Luke 1:46-55). The stage direction establishes that the play was intended as a paraliturigical performance at either matins or vespers, most likely on the feast of the Circumcision (1 January), which was the occasion for the Beauvais Ludus Danielis, or the feast of the Epiphany (6 January). The closing stage direction for Hilarius's Suscitacio Lazari offers the same choice of hymns for matins or vespers. 


\section{Appendix}

This four-stanza hymn is attributed to Fulbert of Chartres (d. 1028). An angel sings the first stanza at the conclusion of the Beauvais Ludus Danielis and as part of various Christmas ceremonies and performances. My base text for the English translation is that of Guido Maria Dreves and Clemens Blume (eds), Analecta hymnica medii aevi, 55 vols (Leipzig, 1886-1922; rpt New York, 1961), 50.283.

Nuntium vobis fero

Nuntium vobis fero de supernis:

Natus est Christus, dominator orbis,

In Bethlem Iudae, sic enim propheta

Dixerat ante.

Hunc canit laetus chorus angelorum,

Stella declarat, veniunt Eoi

Principes digno celebrare cultu Mystica dona.

Tus Deo, murram troclotem humando,

Bratheas regi chryseas decenter,

Dum colunt unum, meminere trino Tres dare terna.

Gloriam trinae monadi canamus, Cum Deo divae genitore proli Flamini nec non ab utroque fuso Corde fideli.

\section{I bring you tidings}

I bring you tidings from on high:

Christ is born, the ruler of the world,

in Bethlehem of Judea, just as the prophet

had foretold.

The joyful chorus of angels sings of him, the star proclaims him, the princes of the East come to worship the mystical gifts

with proper reverence.

Frankincense for the God, costly myrrh for the man to be buried, ${ }^{*}$

golden leaves befitting the king;

while they worship the One, the three remember to give three gifts to the Trinity.

With faithful hearts let us sing glory to the threefold unity,

with God the father to the divine child,

no less to the spirit poured out from both.

10 In its two variant forms, the text reads 'murram troclotem' or 'troclitem'. The adjective is a hapax legomenon that is not found in any of the standard Latin or Greek dictionaries. Morel, Lateinische Hymnen des Mittelalters, 12, finds the term 'unverständlich' (incomprehensible). C. Bennett Pascal plausibly speculates that the phrase originally read 'murra triclites' ['myrrh appropriate to a banquet hall']; see Peter Bergquist (ed.), Orlando di Lasso: The Complete Motets (Madison, WI, 1999), xxiv.

11 The traditional symbolism of the three gifts presented by the Magi (Matt. 2:11) dates back to Origen of Alexandria (d. ca 254), Contra Celsum, 1:60. See Alexander Roberts, James Donaldson, and A. Cleveland Coxe (eds), The Ante-Nicene Fathers, 10 vols (New York, 1907), 4.423. 